\title{
Ídolo, idolatría, fetiche
}

\author{
Maurizio BETTINI \\ Universidad de Siena \\ Traducción de Rayco González
}

(Abstracts y palabras clave al final del artículo)

Propuesto: 11 de diciembre de 2015

Evaluado: 12 de diciembre de 2015

La palabra "ídolo" reenvía inmediatamente a otras dos palabras, que en la cultura occidental han gozado de un éxito extraordinario: "idólatra" e "idolatría". Se trata de compuestos griegos, formados por éidolon, "imagen", y latréuo, "adorar, venerar". Por consiguiente, con éidololátres se define a una persona que "adora las imágenes", de la misma forma que eidololatréia designa el "culto de las imágenes"1. Comencemos diciendo que estamos frente a términos que un griego no habría usado nunca para definir el culto que dedicaba a las estatuas de las propias divinidades. Del mismo modo que polythéia y de otros términos que darán vida a nuestro "politeísmo"2, también eidololátres y eidololatréia, aún siendo términos griegos, no provienen de la civilización griega, sino de la hebraica. Si polythéia, "los muchos dioses", y sus derivados son una creación de Filón de Alejandría, el gran intérprete y alegorista de la Biblia que vivió entre los siglos I a.C y I d.C., el uso de éidolon para indicar las estatuas de culto de los gentiles viene directamente de la traducción en griego de la Biblia hebrea, la llamada de los Setenta, realizada en Alejandría en el siglo III a.C. De hecho, cuando en el texto hebreo original se hablaba de la prohibición de honrar las imágenes de los dioses — como también hacían por hábito los pueblos que no creían en el dios único - para designar el objeto de tal condena, los traductores griegos escogieron, el uso de la palabra éidolon. Por tanto, está en la traducción de los Setenta el acto de nacimiento de los éidola que serán condenados a continuación por la tradición cristiana griega, los idola contra los que lucharán los apologetas latinos, los "ídolos" que constituirán la diana polémica de la cultura cristiana sucesiva, hasta el uso contemporáneo de esta palabra en contextos donde

${ }^{1}$ Las palabras "idólatra" e "idolatría” presentan una haplología respecto a los términos griegos, es decir, la caída de la sílaba -lo- antes de -la- (idololatría>idolatría).

2 Cfr. Bettini, M. Elogio del Politeismo. Quello che possiamo imparare oggi dalle religioni antiche, Bologna, Il Mulino 2014 (traducción española de próxima publicación en Alianza Editorial). 
menos nos esperaríamos encontrarla ${ }^{3}$. Ya, ¿pero qué tipo de imágenes tenían en mente los traductores de Alejandría, cuando definieron precisamente con éidola aquellas adoradas por los gentiles?

En realidad, la palabra éidolon no indica cualquier tipo de imagen, aún menos indica la estatua de culto. Con este término los griegos definían específicamente la imagen inconsistente, vana, engañosa, como la que aparece en los sueños, el reflejo del espejo o la fugitiva sombra de un difunto. En definitiva, se trata de un simulacro que puede caer exclusivamente bajo el sentido de la vista (el término éidolon deriva de la raíz id-, "ver"), y, en cuanto tal, engañoso, inaprensible, como también lo son las imágenes de los sueños o las sombras de los difuntos. Por consiguiente, recurrir a la palabra éidolon para indicar las estatuas de culto de los "otros", implicaba ya una condena intrínseca: en cuanto definidas éidola, las imágenes veneradas por los gentiles eran automáticamente caracterizadas como vanas e inconsistentes ${ }^{4}$. Pablo parece querer poner el acento explícitamente en este carácter de los "ídolos" — su naturaleza de imágenes inconsistentes - cuando formula afirmaciones como esta 5 : "¿quiero decir con esto que la carne sacrificada a los éidola (eidolóthuton) tiene algún valor (tí estin), o que los éidola son algo?”; o también: “cuando todavía eráis paganos (éthne) os dejabáis arrastrar ciegamente al culto de dioses mudos (prós ta éidola áphona)". Los éidola 'no son nada', o sea, son 'mudos'. También Isidoro de Sevilla nos deja una huella interesante del modo en que los idola eran percibidos en su tiempo. Cuando la toma contra aquellos Latini que "sin conocer el griego, como ignorantes que son, dicen que idolum deriva su nombre del engaño (dolus)" 6 . Esta vez, Isidoro, que tantas etimologías fantasiosas nos ha dejado, se tropezó con etimologistas aún más fantasiosos que él mismo. Etimologistas que ciertamente no conocían el griego, pero tenían aún vivo el sentido de lo que la palabra idolum llevaba consigo: el sentimiento de 'falsedad'.

La estrategia lingüística inaugurada por los traductores de Alejandría y seguida luego por la tradición cristiana —o sea, definir las imágenes de culto de los otros con un término que, ya de por sí, implica el carácter de la inconsistencia, de la

3 Cfr. expresiones como "la idolatría no concierne solo a los falsos cultos del paganismo" (Catequismo de la Iglesia Católica 2113), o como "the persecution of Christians by the Roman governement [...] was due to their refusal to participate in the idolatrous imperial cult" (P. Zagorin, How the Idea of Religious Toleration Came to the West, Princeton, Princeton University Press 2011, 690). Esta última afirmación, contenida en sede científica, sorprende especialmente: pero no se trata, en absoluto, de un caso aislado.

4 Cfr. la discusión de D. Barbu, "Idole, idolâtre, idolâtrie", en Les représentations des dieux des autres. Actes du Colloque FIGVRA, Toulouse, 9-11 décembre 2010. C. Bonnet, A. Declerq, I. Slododzianek, eds., Siracusa, Sciascia 2011, pp. 32-49.

5 Carta a los Corintios 1, 10,19; 1, 12, 2. La inconsistencia y la vanidad de las imágenes de los gentiles constituye un rasgo frecuentemente subrayado por los escritores cristianos cuando se habla de éidola o de idola. San Agustín, por ejemplo, no dudará en definir inutilia simulacra las imágenes veneradas por quienes honran los muchos y falsos dioses (S. Agustín, De civitate dei, 6, Praefatio). Nuestra reflexión, exclusivamente ligada al origen del término "ídolo" y a su semántica originaria, no concierne obviamente la inmensa fortuna de la que esta palabra ha gozado posteriormente, y las innumerables transformaciones de su significado. En este mar de problemas y contribuciones podemos recordar M. Halberthal, A. Margalit, Idolatry, Cambridge (Massachusetts), Harvard University Press 1992.

6 San Isidoro de Sevilla, Etymologiae, 8, 11, 14. 
falsedad - es ciertamente hábil, pero no constituye un hecho aislado. Podemos reconocer, de hecho, el mismo procedimiento también en el uso de la palabra "fetiche" para designar las imágenes o los objetos de culto propios de las llamadas religiones primitivas. También esta palabra tiene un origen interesante. En efecto, en latín existe un término, facticius, con el que se indica el producto "fabricado", derivado de un acto del "hacer" (facio), en contraposición a lo que es "natural". En las lenguas romances, de este término se derivaron otros - entre los cuales el portugués feitiço — que han pasado a indicar lo que es "artificial" en el sentido de lo que ha sido realizado a través de magia ${ }^{7}$. El "hacer" que produce un objeto "no natural" es identificado así con el "hacer" de la bruja o del mago: un hacer malvado, que invierte la naturaleza recurriendo a los propios poderes ocultos. Precisamente el término feitiço —o sea, "artefacto mágico, de brujería" - fue usado por los navegantes portugueses del siglo XVI para indicar los artefactos de carácter religioso utilizados por las poblaciones de Guinea y de África occidental. Con este simple acto de nominación, lo que constituía el objeto de culto de las religiones propias de algunos pueblos, mantenía un vínculo con el mundo de lo sobrenatural — se le reconocía así una 'eficacia'-, aunque era degradado automáticamente al rango de producto de la brujería: y, de este modo, se les negaba cualquier legitimidad. La palabra portuguesa, pasada luego al francés como fétiche, gozó de una creciente fortuna después de que el Presidente Charles Des Brosses se sirvió de ella (junto a sustantiva fétichisme y fétichiste) para indicar la fase más primitiva en la historia religiosa de la humanidad, la que preveía el culto de objetos o animales ${ }^{8}$. No es la sede para seguir ulteriormente la historia de una palabra que, por otra parte, ha ejercido una influencia tan grande dentro de los estudios antropológicos e histórico-religiosos (aunque no solo: basta con pensar en el "fetichismo de la mercancía" de Marx o al "fetichismo", entendido como parafilia, del psicoanálisis freudiano) ${ }^{9}$. Lo que interesa aquí es subrayar cómo tanto al definir éidolon (= imagen vana e inconsistente) la estatua de culto de los 'gentiles' o 'paganos', como al llamar con el nombre feitiço (= producto de brujería) el objeto o la imagen venerada por los pueblos africanos, y luego por los 'primitivos' en general, se ha utilizado la misma estrategia de tácita degradación, a través de la lengua, de otros cultos.

\footnotetext{
7 Thesaurus linguae latinae, VI/1, 133-134. S. Agustín, Locutiones in Pentateuchum, 2, 138, junto a simulacra usará la expresión facticii dei. Para los resultados romances cfr. el provenzal fachiz y el español "hechizo", que significan "artístico" aunque también "encantamiento"; el portugués feitiço, del cual feiticeiro, "brujo" (recuérdese los términos italianos fattura, 'hechizo' y fattuchiera, 'hechicera'), es sinónimo del español "hechicero”. Cfr. Meyer-Lübke, Romanisches Etymologisches Lexicon, Heidelberg, Winter 1972, 3132.

8 C. Des Brosses, Du culte des dieux fétiches, ou parallèle de l'ancienne religion de l'Égypte avec la religion actuelle de Nigritie, s.1., s.e., 1760. Cfr. M. Iacono, Le fétichisme. Histoire d'un concept, París, PUF 1992.

9 El uso de estos términos en antropología y en los estudios histórico-religiosos ha sido, además, bastante funesto. A propósito, Marcel Mauss (Année Sociologique, 1907, cit. en Iacono, p. 116) hablará expresamente del "immense malentendu" que existe detrás de términos como "fetiche" y "fetichismo", malentendido debido a a la "aveugle obéissance à l'usage colonial, à les langues franques parlées par les Européens, à la culture occidentale".
} 


\section{RESUMEN}

El autor recorre las tradiciones antiguas para estudiar las raíces etimológicas y culturales de las palabras "ídolo" y "fetiche", mostrando la manipulación y los procesos de cambio de significado que ambos términos han sufrido en los diferentes períodos de la historia cultural y religiosa.

Palabras clave: ídolos, fetiche, religión, cultura, cultos.

\section{Idol, Idolatry and Fetish}

\section{ABSTRACT}

The author reviews in different ancient sources the etymological roots of the terms "idol" and "fetiche", finding the interesting process of manipulation that both terms have suffered during the different periods oh religious and cultural history.

Keywords: idols, fetiche, religion, cult, culture.

\section{RÉSUMÉ}

L'auteur parcourt les sources plus anciennes des raisins étymologiques des mots "idole" et "fétiche", en nous exposant les procès divers de manipulation et de changement de sens que les deux expressions ont souffert pendant les divers périodes de l'histoire culturelle et religieuse.

Mots-clé: idole, fétiche, religion, culte, culture. 